\title{
Distribution and ecology of benthic macroinvertebrates in the Opunohu river catchment, Moorea, French Polynesia
}

\author{
V.H. Resh1 \\ J.R. Barnes ${ }^{2}$ \\ D.A. Craig ${ }^{3}$
}

Keywords : Oceania, Pacific island, stream, benthos, macroinvertebrates.

Distribution and ecology of maçroinvertebrates in the Opunohu River catchment (17 $31^{\prime} \mathrm{S}, 149^{\circ} \mathrm{S} 5 \mathrm{O}^{\prime} \mathrm{W}$ ), Moorea, French Polynesia, were studied at eight sites, which range in altitude from 2 to $335 \mathrm{~m}$, and from 0.4 to $4.0 \mathrm{~km}$ distance from the ocean. Taxa richness per site ranged from 16 to 28 , and was higher in austral spring than austral fall ; 48 taxa were collected over all sites and included 7 species of molluscs, 6 crustaceans, 23 insects, and 6 oligochaetes. Neritid snails and atyid and palaemonid shrimp in the Opunohu have diadromous life cycles : they enter freshwater as juveniles and migrate upstream ; their larval offspring must return to the sea for growth and metamorphosis. These groups generally had larger individuals at upstream than at downstream sites. Human activities such as channeling stream flow through elevated culverts can impede normal upstream migration of diadromous species. Densities of neritid egg capsules were higher in riffle than pool habitats, exhibited seasonality, and were highest at the downstream-most site ; abundance at upstream sites also reflected local habitat conditions. Microhabitat segregation of two species of atyiid shrimp reflected their respective filter-feeding and detritus-gathering feeding mechanisms. High $\mathrm{pH}$ and temperatures in the poorly buffered, cascade headwaters produced high seston loads (3.4 mg/l) that mainly contained diatoms ; in downstream reaches seston concentrations were lower and contained more detritus. Some filter-feeding black fly species occured only in the headwaters. Insect taxa-richness was higher in headwater reaches while mollusc and crustacean richness was higher at sites near the ocean, which supports a tenet of the River Continuum Concept.

Distribution et écologie des macroinvertébrés benthiques dans le bassin de la rivière Opunohu, Moorea, Polynésie française.

Mots clés : Océanie, île du Pacifique, cours d'eau, benthos, macroinvertébrés.

La répartition et l'écologie des macroinvertébrés du bassin de la rivière Opunohu ( $\left.17^{\circ} 31^{\prime} \mathrm{S}, 149^{\circ} \mathrm{S} 50^{\prime} \mathrm{W}\right)$, Moorea, Polynésie Française, ont été étudiées en huit stations échelonnées entre 2 et $335 \mathrm{~m}$ d'altitude, et distantes de 0,4 à 4,0 $\mathrm{km}$ de l'océan. La richesse spécifique par station varie de 16 à 28 et est plus élevée pendant le printemps austral qu'en automne ; 48 taxa ont été récoltés sur l'ensemble des stations et comprennent 7 espèces de mollusques, 6 crustacés, 23 insectes et 6 oligochètes. Les Gastéropodes Neritidae et les Décapodes Atyidae et Palaemonidae présentent des cycles biologiques de type diadrome : ils pénètrent en eau douce sous forme de juvéniles et migrent vers l'amont ; leur descendance larvaire doit retourner en mer pour la croissance et la métamorphose. Les individus de ces groupes systématiques présentent en général une taille supérieure en amont qu'en aval. Les activités humaines telles que la canalisation du cours d'eau dans des buses surélevées par rapport au substratum peuvent réduire considérablement ou interdire les migrations normales des espèces diadromes. Les densités de capsules d'œufs de Neritidae sont plus élevées en habitat lotique que lentique, montrent une saisonalité et sont les plus élevées à la station située le plus en aval ; l'abondance aux stations de l'amont traduit aussi les conditions d'habitat local. La différenciation des microhabitats de deux espèces de Décapodes Atyidae met en évidence leurs stratégies trophiques respectives : filtreurs et collecteurs rassembleurs. $\mathrm{pH}$ et températures élevés dans la cascade de l'amont peu tamponnée sont à l'origine de fortes charges en seston $(3,4 \mathrm{mg} / \mathrm{l})$ qui contiennent surtout des Diatomées ; dans les biefs de l'aval les concentrations en seston sont inférieures et renferment davantage de détritus. Quelques espèces de Simuliidae, filtreuses, sont exclusivement cantonnées dans le secteur le plus en amont. Pour les insectes, la richesse en taxa est plus élevée dans les bief́s de l'amont tandis que la richesse en mollusques et crustacés est supérieure aux stations proches de l'océan, ce qui est en faveur du River Continuum Concept.

1. Department of Entomology, University of California, Berkeley, California 94720, U.S.A.

2. Department of Zoology. Brigham Young University, Provo, Utah 84602, U.S.A.

3. Department of Entomology, University of Alberta, Edmonton T6G 2E3, Alberta, Canada. 


\section{Introduction}

The fauna and flora of islands have been of special interest to biologists for the past two centuries. During this time, research has expanded from Wallace's (1881) discussion of the continuities, discountinuities, and peculiarities in the distribution of island species to examination of dispersal, endemism, speciation mechanisms, and questions of population biotogy, adaptation, adaptive radiation, character displacement, and community ecology (e.g. Carlquist 1974, Williamson 1981, Grant 1986). However, of all island habitats and fauna, that occurring in freshwater streams has probably been the least studied. Expectedly what is perhaps the best-known contribution of island biological research, the development of the Theory of Island Biogeography (MacArthur and Wilson 1967), has been applied to examining colonization dynamics of biota in continental streams (e.g. Minshall et al. 1983, Minshall \& Peterson 1985).

It is unfortunate that island streams have not received much attention because the fauna oftentimes is composed of species with a unique life-history characteristic : many taxa (including macruran crustaceans, neritid snails, anguillid eels, and most gobioid fishes) are diadromous (or amphidromous, according to some authors) - they have evolved the ability to use stream habitats but they produce larvae that must undergo development in the ocean (Ford \& Kinzie 1982, Maciolek \& Ford 1987). The fauna of islands can be diverse : recently Marquet (1987, 1988) and Marquet \& Lamarque (1987) examined the fish, molluscan, and decapod crustacean fauna of selected streams in ten volcanic islands and one atoll of the archipelagoes that comprise French Polynesia ; 63 species in these groups were found.

The purpose of this present study is (1) to provide a detailed description of the macroinvertebrate fauna of one Pacific island stream-catchment and (2) to describe species richness and the macroinvertebrate zonation patterns in this island stream and compare these with zonation patterns described for other types of lotic systems. The system chosen for this study was the Opunohu catchment in Moorea, French Polynesia.

\section{Methods}

\subsection{Study Sites}

French Polynesia is located in the south-central Pacific Ocean and consists of 118 islands, 35 of which are high volcanic islands, the others being low coral islands or atolls ; together they have a surface area of $4,000 \mathrm{~km}^{2}$, surrounded by $2,500,000 \mathrm{~km}^{2}$ of ocean. The islands of French Polynesia range in age from 0.3-4.3 million years old (Craig 1983) and are part of the Indo-Pacific province (which stretches from south Africa to eastern Polynesia). The Society Islands (approximately $16-18^{\circ} \mathrm{S}, 148-152^{\circ} \mathrm{W}$ ) form one of the five archipelagos of French Polynesia and are composed of 14 islands, the largest of which is Tahiti (1042 $\mathrm{km}^{2}$ surface area). Moorea $\left(136 \mathrm{~km}^{2}\right)$ is the third largest of these islands, and is located $18 \mathrm{~km}$ west of Tahiti (Williams 1933, Gabric \& Salvat 1985). It is triangular in shape and about $15 \mathrm{~km}$ along each side (Fig. 1).

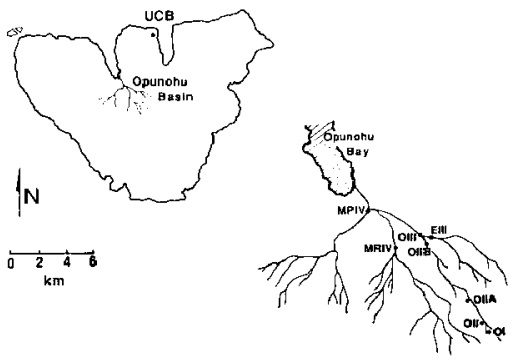

Fig. 1. : Map of Moorea and the study sites in the Opunohu catchment ; UCB = University of California Biological Station.

Moorea is 1.2 million years old and consists of a volcanic core surrounded by reefs. Peaks on this high volcanic island reach $1207 \mathrm{~m}$. The climate is tropical $\left(25-30^{\circ}\right)$ and humid (relative humidity $80-90 \%$ ) with two seasons: one hot and rainy (November to April), the other cooler and drier (May to October). Precipitation on Moorea ranges from $<200 \mathrm{~cm}$ to $>400 \mathrm{~cm}$ per yr at higher elevations; in the Opunohu Valley, the site of this study, the annual average rainfall is $325 \mathrm{~cm}$. The dominant winds are trade winds that blow from the northeast to the southeast $(20-40 \mathrm{~km} / \mathrm{hr}$, up to $60 \mathrm{~km} / \mathrm{hr}$ in austral winter) (Galzin \& Pointier 1985).

The Opunohu Valley comprises one of the two catchments on the north side of the island (Fig. 1;17\%31's, $149^{\circ} 55^{\prime} \mathrm{W}$ ). The name Opunohu derives from the resemblance of the shape of the bay to sthe belly of the stonefish » (in Tahitian " ophu, " belly ; " nohu, ") the venomous stonefish Synanceja verrucosa Block and Schneider, which occurs in the reefs of Opunohu Bay). Before the arrival of Europeans in 1767, the Opunohu Valley was the most significant religious center of the Windward Islands ; major portions of the Opunohu Valley are now 
controlled by the Territorial Government for agriculture experimentation (Galzin \& Pointier 1985).

Eight sites in the main stream and tributaries of the Opunohu Valley were chosen for study (Fig. 1). This study is based on collections made in austral fall (roughly corresponding to the beginning of the dry season) during March-May 1988 and March 1989, and in austral spring (the beginning of the wet season) during OctoberNovember 1989. Study sites are described in descending order from upstream to downstream (Fig, 1).

The upstream-most site is a first-order stream (site 0I ; 0 representing Opunohu, I the first-order segment) flowing down a cascade that consisted of a sheer rock-face (composed of basalt) having large amounts of moss and algal growth. This is located on the north-facing slope of Mt. Tohivea, which eventually rises to $1207 \mathrm{~m}$. At the base of the cascade are large boulders with interspersed cobbles. Although the cascade has an open canopy, the pools forming below it have a closed canopy consisting of Tahitian chestnut [Legumenoceae, Inocarpus fagiferus (Parkinson) Fosbergl and Pandanus. This site is reached using a south-directed trail from the Belvedere, a well-known observation point. The $\mathrm{pH}$ of the water is higher than at other sites in this stream (Table 1), but not higher than found at other cascades on the island (Craig, Resh \& Barnes, unpubl. data). Diatoms were scraped off stones at each site and were prepared according to the methods outlined in St. Clair \& Rushforth (1977); at site 0 I diatoms are abundant, with over 30 species represented. The numerically dominant species is Rhopalodia gibba (Ehr.) O. Muell.

Table 1: Physical characteristiçs of study sites in the Opunohu catchment; ranges (in parentheses) are based on measurements made March-May 1988 and represent from three to five observations.

Site

ph-1

conductivity in $\mu \mathrm{S} / \mathrm{cm}$

velocity in $\mathrm{cm} / \mathrm{s}$

width $\ln \mathbf{m}$

depth in $m$

discharge in $\mathrm{cm} 3 / \mathrm{sec}$

temperature air/water in ${ }^{\circ} \mathrm{C}$

seston in $\mathrm{mg} / \mathrm{I}$

elevation in $\mathrm{m}$

slope in degrees

distance from mouth in $\mathrm{km}$

Site

pH

conductivity in $\mu \mathrm{S} / \mathrm{cm}$

velocity in $\mathrm{cm} / \mathrm{s}$

width in $m$

depth in $\mathrm{m}$

discharge in $\mathrm{cm} 3 / \mathrm{sec}$

temperature alr/water in ${ }^{\circ} \mathrm{C}$

seston In $\mathrm{mg} /$

elevation in $\mathrm{m}$

stape In degrees

distance from mouth in $\mathrm{km}$ ol

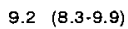

$113(100-140)$

$27(24-30)$

5

$0.001-0.3$

538

26

$\begin{array}{cc}(25-28) / 26 & (21-30) \\ 2.60 & \\ 335 & \\ 60 \\ 6.0\end{array}$

Oll
7.5
$(90-100)$
52
2
$>0.6$
562

$23 / 23$

1.67

213

17

8.7
OIIA

$7.6(7.3-7.8)$

$120(110-140)$

$113(54-177)$

2

$0.2-0.3$

882

$27(25-28) / 23$

$0.19(0.04-0.36)$

122

$1 \mathrm{~g}$

9.1
OIIB

$$
7.5
$$

$95(90-100)$

76

3

$0.2-0.3$

21,204

$25 / 24$

0.5

12

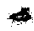

1.6

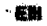

$7.6 \quad(7.5-7.7)$

$110(130-150)$

$153(125-180$

2

$0.1 \cdot 0.2$

23,000

$24(21-27) / 23 \quad(22-24)$

$1.7(1.24-2.07)$

6

4

1.8 ont

$7.3 \quad(7.3-7.5)$

$125(120-130)$

95

5

$0.1 \cdot 0.4$

40,389

$23 / 21$

1.83

$<5$

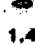

MRIV

MPIV

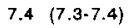

7.6

$140(120-140)$

120

108

12

12

$0.5-1.0$

$>60,480$

$>133,900$

$25 / 23$

2.09

2

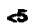


The next downst ream site is a second-order reach of the Opunohu (site 0II), located just east of the Belvedere lookout. At this site the stream is steep sided and consists of large boulders with pools interspersed. Some moss is present on rock surfaces. Tahitian chestnut dominates the closed canopy. The diatom community consists of approximately 25 species and is numerically dominated by Achnanthes lanceolata (Breb.) Grun. and Achnanthes exiqua Grun.

Another second-order site is located near Marae de Titiroa (site 0IIA). This site, at the remains of an ancient temple, has a near-continuous series of pools; some side channels are also present. Moss occurs on rocks and banks, and the dominant plant in the closed canopy is Tahitian chestnut. The diatom community consists of over 30 species ; $A$, lanceolata is numerically dominant.

The next collection site is a second-order segment of the Opunohu (site OIIB). Here (and at all other sites downstream), a riffle-pool sequence replaces the pool-topool geomorphology of the upper two sites. The closed canopy is composed of Tahitian chestnut and hibiscus (Malvaceae, Hibiscus rosa-sinensis L). Diatoms are sparse and consists of 15 species, with Navicula cincta (Ehr.) Kuetz dominant.

East of site 0IIB, an unnamed third-order stream enters the Opunohu (site EIII). This site also has a closed canopy (with similar vegetation as OIIB). A major difference between site EIII and site OIIB involves the method by which a dirt road (the Pao Pao-Marae-Belvedere Road) crosses the stream. At site OIIB the small bridge is built on arches, which allows free stream-flow over the substrate from above to below the bridge. In contrast, at site EIII the road has been built over two elevated pipe-culverts ; rather than having continuous flow over the substrate (as at site OIIB), at the downstream end of the culvert a waterfall drops $0.3 \mathrm{~m}$ to the substrate. The diatom community at site EIIIU contains about 30 species and is numerically dominated by $A$. ianceolata.

The next site downstream, a third-order segment of the Opunohu (sjte 0111), is located 100-m east of the junction of the Pao Pao-Marae-Belvedere Road. Tahitian chestnut and hibiscus dominates the partially open canopy ; some coffee is grown upland. The diatom community there contains 15 species and is numerically dominated by $A$. exiqua.

A fourth-order stream enters the Opunohu from the Mouaroa valley (site MRIV) and was sampled at the road bridge. The canopy is approximately $50 \%$ open, and is composed of hibiscus and Tahitian chestnut. Agricultural practices (e.g. orchards, cattle and pig farming) influence water quality at this site. The jagged spires of the Mouaroa Mountain (where the headwaters of this tributary occurs) was the mythical Bali $H^{\prime} a i$ in the 1958 movie South Pacific. The diatom community contains over 40 species and is dominated by $A$. lanceolata, $A$. exiqua, N. cincta, and Nitzschia dissipata (Kuetzing) Grunow.

Downstream of the above sites and $0.4 \mathrm{~km}$ upstream from Opunohu Bay, another fourth-order stream that drains the northeast-facing slope of Mouaroa Mountain and the Mouapu valley enters the Opunohu (site MPIV). This site was sampled at the road bridge. It has a open canopy but immediately upstream and downstream there is a closed canopy dominated by hibiscus, some cultivated mango, and scattered Tahitian chestnut. Cattle grazing occurs in adjacent pastures. The diatom community at this site contains 15 species and is dominated by $A$. exi$q u a$ and $N$. dissipata. The tributaries that flow through sites MRIV and MPIV enter the Opunohu about $150-\mathrm{m}$ east of site MPIV creating a swampy, mud-bottom confluence that intermixes with the saline waters of Opunohu Bay.

Physical characteristics of the study sites are presented in Table 1. Marquet (1988) presented conductivity and water chemistry values for four other Moorean streams (not the Opunohu). Conductivity ranged from $130-220 \mu^{5}$ $\mathrm{cm}^{-1}$, $\mathrm{pH} 7.5-8.4, \mathrm{NO}_{3} 0.2-1.2 \mathrm{ppm}, \mathrm{SiO}_{4} 12-60 \mathrm{ppm}$.

\subsection{Benthic Sampling Methods}

Four quantitative measures of the macrobenthos were taken at each site in March-May 1988 (hereafter referred 10 as austral fall) and October-November 1989 (as austral spring) : (1) Three separate leaf packs were randomlv collected from the stream, and specimens contained within were removed by washing each leaf with freshwater through a $110-\mu \mathrm{m}$ sieve. Sorting was done under a dissecting microscope. The majority of water was then hand pressed from the leaf pack and each leaf pack was weighed to the nearest gram. Numbers of animals were corrected to reflect a unit weight $(100 \mathrm{~g}$ wet-weight). At site OI, the headwater cascade, leaf packs were not present along the sheer cascade surface and a sample of moss was substituted (presence but not abundance of macroinvertebrates was determined for this measure at this site). (2) A coarse-mesh $(500 \mu \mathrm{m}) \mathrm{D}$-ftame net was used to sample pools, riffles, and streamside vegetation ; stones were also overturned and their surfaces scraped into the net. General collections were made with the D-frame net for 10 minutes at each site. The fauna was separated from debris by floatation, then sorted under a dissecting microscope. (3) A small aquarium net was used to collect the fauna occurring in the shallow-run areas of rapid flow (e.g. typical Simulium black fly habitat). Specimens were removed from the substrates by scraping the rocks with a stiff brush. The sample represented an area covered within 2 minutes. (4) Egg capsules of neritid snails were counted on from 50 to over 100 boulder-sized $(200 \mathrm{~mm}$ in long axis) stones collected at a site. During March 1989, these 
and other qualitative sampling approaches were used to further characterize the distribution of macroinvertebrates in this stream, but these collections were only used to indicate presence or absence.

Macroinvertebrate identifications involved regional keys, specialist determinations (see acknowledgments) and reference collections available at the Centre de l'Environment de Moorea, Muséum d'Histoire Naturelle et Ecole Pratique des Hautes Etudes (Papeitoa, Moorea).

Size spectra of numerically dominant taxa were determined at each site. Shrimp measurements were made from the tip of the rostrum to the end of the telson. Neritid snail measurements were made along the longest axis of the shell. Thiarid (= melaniid) snail measurements were made across the widest part of the operculum. Larval damselfly measurements were made from the tip of the head to the last abdominal segment.

Seston was measured by filtering $750-1500 \mathrm{ml}$ (depending on suspended loads) through pre-weighed Millipore Type HA $0.45 \mu \mathrm{m}$ filters ; samples were then dried for $24 \mathrm{~h}$ a! $60^{\circ} \mathrm{C}$. Velocity and discharge was determined using the " ruler " technique described by Craig (1987a). Conductivity, $\mathrm{pH}$, and temperature were measured with ColePalmer " wands. Small, aerated aquaria (4 l) were used to observe snail movements.

\section{The fauna}

\subsection{Macroinvertebrate Species Richness}

We collected a variety of gastropod molluses, crustaceans, insects, oligochaetes, and other groups of macroinvertebrates among the 48 taxa found at the eight sites during the course of this study (Table 2). Different sampling techniques yielded different species. Molluses and large crustaceans were mainly found with D-frame collections, whereas insects, small atyid shrimp, and oligochaetes were mainly found in riffle and leaf-pack collections. This bias reflects the different habitats occupied by these organisms and the organisms' size.

From 16 to 28 different species of macroinvertebrates were collected at a site, with highest species richness occurring at upstream site OII and downstream site MPIV (Table 2 ). Richness was higher in austral spring than austral fall collections. Thirteen taxa only occurred at one site ; 23 taxa were only collected during one season (usually austral spring). The thiarid snail $M$. tuberculata, oribatid mites, and the millipede $O$. gracilis were the only taxa that occurred at each site and at both seasons.

Overall, the macroinvertebrate species richness of the Opunohu is rather depauperate when compared with that found in either temperate or tropical continental streams, in island streams that are close to continents, or on islands that are much larger in size. Isolation of the Society Islands and the short life span and weak flying-ability of many aquatic insects limits the number of insect species that could colonize this stream. In fact, much of the Opunohu fauna represents groups that are primarily of marine origin (see below).

The low richness of the Opunohu probably results from similar factors that are believed to be responsible for the low diversity of the coral-reef fauna of this area (Gabrie \& Salvat 1985). French Polynesia lies at the extreme eastern end of the Indo-Pacific Province, a cline of decreasing species wealth. Distance from the center of dispersion, coupled with the general direction of ocean currents and dominant winds hinder dispersion from the western Pacific to the central Pacific, which reduces numbers of potential colonists. Ford \& Kinzie (1982) proposed that the number of species found in streams on oceanic islands is roughly proportional to an island's or archipelago's distance from the Indo-Malaysian region. Recently, however, Haynes (1990) proposed that total area of water on an island was the main factor influencing the number of species of freshwater gastropods on Pacific islands.

\subsection{Mollusca}

The molluscan fauna of the Opunohu is composed of two gastropod families (Table 2), the Neritidae and the Thiaridae (or Melaniidae). These are the two most important gastropod families that occur in rivers and streams of the Pacific islands (Haynes 1988). Five genera and at least 33 species of neritids occur in Pacific island (also referred to as Oceania) streams; apart from the four endemic Hawaiian species, the other 29 species occur throughout Oceania, southeast Asia, and New Guinea (Haynes 1988). Starmühlner (1976) provides a monographic treatment of the systematics, distribution, and biology of Neritidae in Pacific island streams.

\subsubsection{Neritid snails}

Most freshwater neritid snails are diadromous : they enter freshwater habitats as small snails from the sea ; after growing to adult sizes and reproducing, their veliger larvae return to the marine or estuarine environment and undergo metamorphosis to small snails that then return to fresh water. 
Table 2 : Fauna collected at eight sites in the Opunohu River catchment, Moorea, French Polynesia : March-May 1988 (AF) and October-November 1989 (AS). - Abbreviations : D : D-frame net collections ; $L$; leaf pack collections (densities expressed as numbers $/ 100 \mathrm{~g}$ wet-weight of leaves) ; $\mathbf{R}$ : shallow-run collections with aquarium net ; number in parentheses is total number of individuals of that taxon collected at that site; dash (-) indicates species was not collected at that site. - Superscripts : asterisk (*) means species was collected but densities were not quantified; ${ }^{1}$ moss sample rather leaf pack samples taken (densities not quantified) $;{ }^{2}$ found in supplementary collections in March $1989 ;{ }^{3}$ taxa not separated in samples.

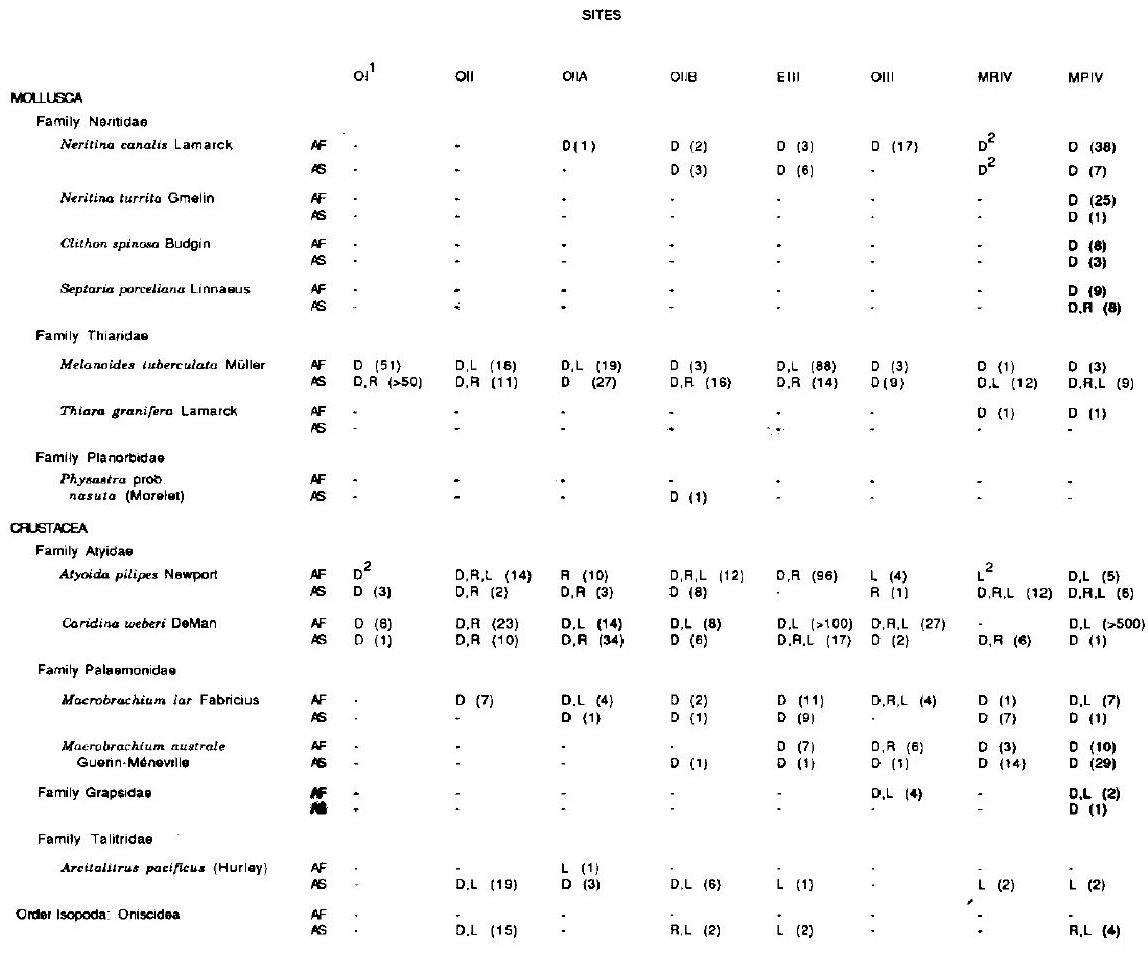

NSECTA

Order Odonata

Family Coenagnionida

Pacificagrion sp.

$\begin{array}{llll}\text { AF } & D(4) & D, L & (24) \\ \text { AS } & \text { A (1) } & \text { D.L (2) } \\ \text { AF } & \text { F (2) } & -\end{array}$

$\begin{array}{ll}D_{(B)}^{(B)} & D, L(20) \\ L(3) & L(2) \\ - & \vdots\end{array}$

D.L (4)
$\vdots \quad$

D (1) 
Table 2. (continued)

$\begin{array}{lllll}\text { OI }^{1} \text { OII OIIA OII } & \text { OII }\end{array}$

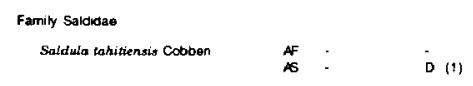

Order Diptera

Family Chironomidae

Polypedilum sp.

n Digrolen dipes sp

Tanytarsus sp.

Thienemanniella sp

Orthocladiinae

Family Ceratopogonidae

Forcipomyinae

ne Culieoides sp.

Family Simulitidae

Simuliam cataractarum Cragg

Simulium Lotii Craig

Simulium malardei Craig

Simutium oviceps Edwards

Simulium tahitiense Edwards

S. exasperens Craig

Family Ephydndae

Apuvill ut cheesemanoe Edwards

Fartily Psyehodidae

Family Scionyzidae

Farrily Tipulidas

nr Ormasia sp

nr Aniocha sp.

Ordar Leproptora

Farnily Pyralidas

Order Colooptera

Family Hyorophilidae

Hydroblinae

\begin{tabular}{|c|c|c|c|c|c|c|c|c|}
\hline AF & $\begin{array}{l}\text { R.L } \quad(3500) \\
\text { D.L.R }(263)\end{array}$ & $\begin{array}{ll}\text { A,L } & (235) \\
\text { L.R } & (233)\end{array}$ & $\begin{array}{l}L \quad\{104\} \\
\text { O.L.R }(111)\end{array}$ & $\begin{array}{l}L \quad(135) \\
\text { O.L.R }(107\}\end{array}$ & $\begin{array}{l}L \quad(36) \\
L, R(10)\end{array}$ & $\bar{L}_{\text {L }} \mathbf{R}(9)$ & $\begin{array}{l}\text { L. }(120) \\
\text { L. }{ }^{(93)}\end{array}$ & $\begin{array}{l}\mathrm{L}(105 ; \\
\mathrm{L}(3)\end{array}$ \\
\hline AF & : & A (15) & $\begin{array}{l}L(12) \\
B(7)\end{array}$ & : & $\begin{array}{ll}L & (5) \\
R & (15)\end{array}$ & $\begin{array}{ll}L & (2) \\
R & (5)\end{array}$ & $\begin{array}{l}\operatorname{L}\{(2) \\
\operatorname{Lig}(3)\end{array}$ & $\begin{array}{ll}L & (4) \\
R & \text { (1) }\end{array}$ \\
\hline AF & $\dot{D} . \mathrm{L} . \mathrm{A} \quad$ (229) & : & : & : & i (1) & $\dot{L}$ (2) & L.A (17) & i (11) \\
\hline$\stackrel{A F}{A S}$ & $\bar{A}(2)$ & A (1) & : & : & R (1) & : & : & : \\
\hline AF & - & $i(1)$ & : & : & $\dot{R}(1)$ & : & : & - \\
\hline AS & - & $\llcorner\quad\{5\}$ & $\dot{.}$ & : & : & : & : & : \\
\hline AF & R.L $(>500)$ & A.L (52) & : & : & R (1) & ค (1) & $\bar{R}, \mathrm{~L}(3)$ & $\overline{\text { P (I) }}$ \\
\hline
\end{tabular}

$\begin{array}{lll}\text { AF } & \text { O.A } & \text { (32) } \\ \text { AS } & R, L & (175)\end{array}$

A :

Af P (1)

AF

AF:

Af - F (4)

As $\begin{array}{lll}\text { AF } & \text { D.R.L (1:) } & R(1) \\ \text { AS } & \text { D.R.L (28) } & \text { R (7) }\end{array}$

Af L

Af:

L (1)
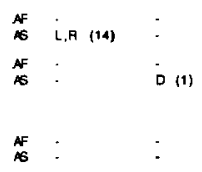

i (1)

L (1)

(1) 
Table 2, (continued)
$\mathrm{Oi}^{1}$
all
OlA
이
EHII
에
MPIV
MPV

ACARINA

Order Oribatida

\section{Family Masaconothrida $\theta$}

Inimadaconothrus sp. 3

$\begin{array}{lllll}\text { AF } & R, L\langle>300) & R(>50) & L^{*} & L^{*} \\ \text { AS } & L, R(>900) & L, R(85) & \text { L.R (22) } & L(17)\end{array}$

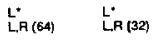

$\begin{array}{ll}L^{*} & \text { L'. }(30) \quad \text { L.A (62) }\end{array}$

Fanily Hydrozyetiose

Hydrozetes sp. 3

DIPLOPODA

Family Paradoxosomatidae

Oxidus gracilis (Koch)

$\begin{array}{llll}\text { AF } & D^{\prime} & D^{*} & D^{*} \\ \text { AS } & D_{(3)} & D, L(12) & D^{(1)}\end{array}$

$\mathrm{D}^{*}(\mathbf{B})$

$D^{*}$
D (13)

$\mathbf{D}^{*}$ (1)

$\begin{array}{ll}D^{*} & D^{*} \\ D, L(2) & D(1)\end{array}$

PLATYHELMINTHES

Class Tridadida

OLIGOCHAETA

Family Tubificidae
Family Lumbricitas
Family Naididae
Pristine manoni Alyer
Pristine proboscidea Beddard
Ailonais inaequatis Stephenson
Altongis pectinate Stephenson
NEMATODA
Mesodoryaimus op.

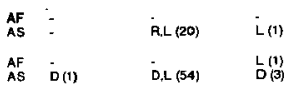

AF D(1)

D.L $(54)$

$\mathrm{D}(3)$

AF :

AF

AF -

A,L (2)

$L(5)$
$L(20)$

AF -

AF
L(2)

L(2)

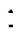

Mesodoryaimus sp.

AF

TOTAL NUMBER OF TAXA $\begin{array}{ll}\text { AF } & 10<+1^{2} \\ \text { AS } & 17 \\ \text { son } & 19\end{array}$

TOTAL NUMBER OF INSECT TAXA

$\begin{array}{rr}\text { AF } & 6 \\ \text { AS } & 10\end{array}$

eitctier season 12

TOTAL NUMBEA OF MOLLUSCS AND AF $2\left(t+1^{2}\right.$,

CRUSTACEANS

$\begin{array}{rr}\text { AS } & 3 \\ \text { etther season } & 3\end{array}$

13
21
27

15

17

19

7
10
14

6

6
L(2)

$$
\text { i (20) }
$$$$
L \text { (6) }
$$$$
\text { L(1) }
$$

13

21

24

12

13

16.

16

3

3

$\mathbf{5}$
$\mathbf{9}$
$\mathbf{9}$
5

8

(1)
6 
It has been suggested that invasion of fresh waters has occurred several times in the Neritidae and that each fresh water genus probably represents a separate line of evolution (Haynes 1988 and references therein). Neritid snails graze on periphyton and at sites in the Opunohu where they are common, periphyton is lacking; where they are absent (e.g. site MRIV) there is a discernible biofilm on the rocks. Bourne (1908), Pointier (1986), and Starmuihlner (1976) provide accounts of the general biology of neritids, and Ford (1979) conducted a detailed life history study of the endemic Hawaiian neritid Neritina granosa Sowerby. The upstream migrations of neritid snails, often occurring in narrow lines tens of meters long (e.g. Schneider \& Frost 1986) are dramatic sights and may be in response to hydraulic forces (Statzner et al. 1988).

$N$. canalis is the most widely distributed neritid species in the Opunohu, oceurring at site OllA and all downstream sites (which represents an elevational range from 2 to $122 \mathrm{~m}$ ). We also found a few scars representing old egg capsules of what is most likely $N$. canalis at site OII (which would be a range from 2 to $213 \mathrm{~m})$. Marquet $(1987,1988)$ found this species at elevations from $10-400 \mathrm{~m}$ in his survey of Tahiti and Moorea. Haynes (1984) reported that this species occurs in fast-flowing streams on Fiji. In the Opunohu we have found it on boulders in fastflowing sections but not in madicolous habitats (i.e. habitats that consist of thin sheets of water flowing over rock faces, Vaillant 1955, Hynes 1970). This species is also known from New Guinea, Solomon Islands, Vanuatu, Samoa, and Fiji (Haynes 1988).

N. turrita was only found at site MPIV. Marquet $(1987,1988)$ found it from $0-5 \mathrm{~m}$ elevation in his survey of Tahiti and Moorea. Haynes (1985) found it occurring on mud substrates in current from $0-10 \mathrm{~cm} / \mathrm{s}$ in a Fijian stream, and we found it attached to boulders and smaller rocks in the Opunohu. Despite its restricted distribution to site MPIV, this species was the most motile neritid in our aquarium rearings ; each day, the majority of individuals would crawl out of aquaria. This species is also known from Southeast Asia, New Guinea, Palau, Caroline islands, New Caledonia, Fiji, and Samoa (Haynes 1988).

C. spinosa is also limited to site MPIV. Marquet (1987, 1988) found it from $0-10 \mathrm{~m}$ elevation in his survey of Tahiti and Moorea. Haynes (1985) reported that it occurred on rocks in current $0-10 \mathrm{~cm} / \mathrm{s}$ in a Fijian stream. We found it attached to rocks, but it usually dropped off as the rock was being removed from the stream bottom. The shell of this species has a ring of six or so long, thin spines that project backwards. This species is also known from Southeast Asia, New Guinea, and Fiji (Haynes 1988).

S. porcellana was the fourth neritid species found in the Opunohu and, like the two previous species, it was only present at Station MPIV. Haynes (1985) and Starmihhlner (1976) found this species occurring at $30-100 \mathrm{~cm} / \mathrm{s}$ current in a Fijian stream. We found it attached to boulders in fast-flowing water. In other streams on Moorea (e.g. the cascade of Afareaitu) we found this species occurring at over 100 m elevation, at distances greater than $1 \mathrm{~km}$ from the ocean, and even in the madicolous habitats of the cascade. Marquet $(1987,1988)$ found it from 5-100 $m$ elevation in his survey of Tahiti and Moorea. In $F i j i$, Haynes (1985) found $S$. porcellana occurring $77 \mathrm{~km}$ from the sea! Why we only found it at the downstream-most site of the Opunohu is unclear. This species was the least motile of the snails in the aquarium rearings; it generally stayed attached to the aquaria sides or the undersides of stones. This species resembles a limpet, with no columella or visible operculum. It is also known from Southeast Asia and most other Pacific Islands groups, except Hawaii (Haynes 1988). Septaria is sometines considered to be a separate family, the Septaridae (Haynes 1984).

The effects of $S$. porcellana grazing on algae at site MPIV was obvious : substrate patches cleared of periphyton often surrounded larger individuals. Experimental studies have shown that snails and other grazing invertebrates in streams may reduce periphyton biomass but actually increase primary production rates (Lamberti \& Moore 1984).

Numbers of boulders that had egg capsules of neritid snails at tached and the number of egg capsules per boulder was highest at site MPIV and lowest at site MRIV (possibly refecting the higher siltation at this site); neritid egg capsules were absent at sites OI and OII (Table 3). Higher proportions of boulders ( $-200 \mathrm{~mm}$ in longest axis) than cobbles $(-100 \mathrm{~mm})$ contained neritid egg capsules at MPIV, and densities were also higher (Table 3). The neritid egg capsules observed at site MPIV 
Table 3 : Proportions of substrates containing egg capsules of neritid snails, and densities (with one standard error) of neritid snails, at eight sites in the Opunohu River catchment, as determined April 15-May 1, 1988 (AF) and October 20-November 15, 1989 (AS). Boulders are particles with $-200 \mathrm{~mm}$ long axis, cobbles $-100 \mathrm{~mm}$ long axis.

\begin{tabular}{|c|c|c|c|c|c|c|c|c|c|}
\hline & & $\begin{array}{c}\text { Ol-OI } \\
\text { (bouider) }\end{array}$ & $\begin{array}{c}\text { OllA } \\
\text { (boulder) }\end{array}$ & $\begin{array}{c}\text { OllB } \\
\text { (boulder) }\end{array}$ & $\begin{array}{c}\text { Ell1 } \\
\text { (boulder) }\end{array}$ & $\begin{array}{c}\text { Olll } \\
\text { (boulder) }\end{array}$ & $\begin{array}{c}\text { MRIV } \\
\text { (boulder) }\end{array}$ & $\begin{array}{c}\text { MPIV } \\
\text { (boulder) }\end{array}$ & $\begin{array}{c}\text { MPIV } \\
\text { (cobble) }\end{array}$ \\
\hline Number of rocks examined & $\stackrel{A F}{A S}$ & $\begin{array}{l}125 \\
125\end{array}$ & $\begin{array}{l}101 \\
101\end{array}$ & $\begin{array}{l}99 \\
50\end{array}$ & $\begin{array}{l}50 \\
50\end{array}$ & $\begin{array}{r}60 \\
100\end{array}$ & $\begin{array}{r}50 \\
101\end{array}$ & $\begin{array}{l}50 \\
50\end{array}$ & $\begin{array}{l}50 \\
50\end{array}$ \\
\hline $\begin{array}{l}\% \text { of rocks containing } \\
\text { neritid eggs }\end{array}$ & $\stackrel{A F}{A S}$ & $\begin{array}{l}0 \\
0\end{array}$ & $\begin{array}{r}10 \% \\
8 \%\end{array}$ & $\begin{array}{l}14 \% \\
46 \%\end{array}$ & $\begin{array}{l}64 \% \\
16 \%\end{array}$ & $\begin{array}{r}17 \% \\
4 \%\end{array}$ & $\begin{array}{l}4 \% \\
2 \%\end{array}$ & $\begin{array}{r}86 \% \\
100 \%\end{array}$ & $\begin{array}{l}70 \% \\
74 \%\end{array}$ \\
\hline $\begin{array}{l}\text { Mean number (one SE) of } \\
\text { neritid eggs/rock }\end{array}$ & AF & $\begin{array}{l}0 \\
0\end{array}$ & $\begin{array}{ll}2.6 & (1.0) \\
3.0 & (1.2)\end{array}$ & $\begin{aligned} 7.9 & (3.1) \\
30.0 & (8.1)\end{aligned}$ & $\begin{array}{ll}34.4 & (9.3) \\
11.5 & (6.5)\end{array}$ & $\begin{array}{ll}3.6 & (1.3) \\
0.5 & (0.3)\end{array}$ & $\begin{array}{ll}0.3 & (0.2) \\
0.3 & (0.3)\end{array}$ & $\begin{aligned} 85.2 & (12.1) \\
113.3 & (11.8)\end{aligned}$ & $\begin{array}{ll}26.9 & (4.9) \\
26.1 & (4.2)\end{array}$ \\
\hline
\end{tabular}

may represent as many as four species of snails (Table 2). Resh, B. Benis-Steger, and Barnes (unpubl. data) examined neritid egg capsule-densities in two habitats (a riffle and a pool) at site MPIV on ten occasions in 1989. Densities were consistantly higher in the riffle than the pool, and showed seasonality : densities peaked in the riffle in September (101 egg capsules $/ 100 \mathrm{~cm}^{2}$ ) and in the pool in November (22 egg capsules $\left./ 100 \mathrm{~cm}^{2}\right)$; densities were lowest in both habitats in March and December.

Based on adult snail distribution, egg capsules at sites MRIV and upstream are probably only $N$. canalis. Neither numbers of boulders containing neritid egg capsules nor densities of egg capsules /boulder show regular downstream-to-upstream decline (Table 3), indicating that local factors rather than only distance from the marine environment may be affecting abundance of the snail egg capsules.

In the Opunohu, $N$. canalis snails generally increased in size from downstream to upstream reaches (Table 4). A Similar pattern of increasing sizes in upstream reaches has been found for Neritina granulosa in Hawaiian streams (Ford 1979).

In the descriptions it was noted that sites OIIB and EIII are both crossed by the same road, but that the flow-through system under the road at each site differs. At site OIIB there are two arches over the natural substrate ; at site EIII, an elevated culvert is separated from the downstream substrate by a $0.3 \mathrm{~m}$ distance. To examine the consequences of these two types of construction, samples were taken above and below the road at both sites. Little difference was found for any faunal components above and below either site OIIB or EIII at either season, except for $N$. canalis at site EIII during both austral fall and austral spring. Below the elevated culvert, $N$. canalis adults were found in both seasons, and egg capsules were present on $64 \%$ of the boulders with a mean density of 344 egg capsules per boulder in austral fall, and on $16 \%$ of the boulders with a density of 11.5 per boulder in austral spring (Table 3 ). In contrast, no neritid adults were found above the elevated culvert in either season, only one egg capsule was found in austral fall ( $2 \%$ of the boulders examined with a density 0.02 egg capsules per boulder), and none were found in austral spring. We did observe a single, large $N$. canalis attempting to enter the pipe culvert (a madicolous habitat that this species avoided at other sites), which may explain how an egg capsule could occur above the culvert.

The difference in numbers of $N$. canalis above and below the road at site EIII is analogous to that which can result from natural geomorphic barriers such as waterfalls and plunge pools that separate populations of neritid snails in Hawaii (e.g. Maciolek 1978, Ford 1979). In terms of the objectives of this study, it was fortunate that the elevated culvert was constructed at site EIII and the flow-through system at OIIB, and not vice-versa, or the neritid distribution patterns observed would have been biased by these activities. Others (Maciolek 1975, Timbol \& 
Table 4 : Mean (and range of sizes) of selected macroinvertebrates at eight sites in the Opunohu River catchment. See text for description of how measurements were made. Dash (-) indicates species did not occur at that site.

\begin{tabular}{|c|c|c|c|c|c|c|c|c|c|}
\hline Site & & $\mathbf{a}$ & Oll & OIIA & OII & E॥E & OIII & MAFV & MPiV \\
\hline N. canalis (in mm) & AS & - & . & 24.0 & $\begin{array}{c}29.0 \\
(26.32) \\
24.5 \\
(21-26)\end{array}$ & $\begin{array}{c}27.0 \\
(26-29) \\
27.3 \\
(24-31)\end{array}$ & 26.0 & - & $\begin{array}{c}10.4 \\
(2.18) \\
16.2 \\
(2-30)\end{array}$ \\
\hline M. tuberculato (in $\mathrm{mm}$ ) & $\begin{array}{l}\text { Af } \\
\text { AS }\end{array}$ & $\begin{array}{c}4.6 \\
(1.7) \\
4.2 \\
(2.7)\end{array}$ & $\begin{array}{c}4.7 \\
(1 \cdot 7) \\
4.1 \\
(2 \cdot 7)\end{array}$ & $\begin{array}{c}4.8 \\
(1.7) \\
5.0 \\
(2 \cdot 7)\end{array}$ & $\begin{array}{c}2.7 \\
(2-4) \\
4.2 \\
(1-7)\end{array}$ & $\begin{array}{c}5.1 \\
(1.8) \\
3.6 \\
(3-6)\end{array}$ & $\begin{array}{c}5.0 \\
(3.7) \\
3.9 \\
(2.7)\end{array}$ & $\begin{array}{c}1.0 \\
3.6 \\
(2 \cdot 5)\end{array}$ & $\begin{array}{c}4.3 \\
(3.5) \\
4.0 \\
(3 \cdot 6)\end{array}$ \\
\hline A. piliper $(\mathrm{in} \mathrm{cm})$ & $\begin{array}{l}\text { AF } \\
\text { AS }\end{array}$ & $\begin{array}{c}1.6 \\
(1.4 \cdot 1.7)\end{array}$ & $\begin{array}{c}1.4 \\
(0.7 \cdot 3.2\} \\
1.7 \\
\{1.6 \cdot 1.8\}\end{array}$ & $\begin{array}{c}2.5 \\
\{1.5 \cdot 3.2\} \\
1.7 \\
\{1.5 \cdot 2.0\}\end{array}$ & $\begin{array}{c}2.1 \\
(0.5-2.5) \\
2.4 \\
(1.6 \cdot 3.4)\end{array}$ & $(1.1-3.4)$ & $\left(\begin{array}{c}1.0 \\
1.2\end{array}\right.$ & $(0.9 \cdot 1.0)$ & $\begin{array}{c}1.3 \\
\{1.1-1.4\} \\
0.6 \\
\{0.5-1.0\rangle\end{array}$ \\
\hline c. weberi (in $\mathrm{cm}$ ) & $\begin{array}{l}\text { AF } \\
\text { AS }\end{array}$ & $\begin{array}{c}1.5 \\
(i .0 \cdot 1.7)\end{array}$ & $\begin{array}{c}1.6 \\
(1.0-2.3) \\
1.7 \\
(1.3-2.1)\end{array}$ & $\begin{array}{c}1.6 \\
(1.0 .2 .5) \\
2.2 \\
(1.7 \cdot 2.8)\end{array}$ & $\begin{array}{c}0.8 \\
(0.6-1.8) \\
1.2 \\
(0.8-2.0)\end{array}$ & $\begin{array}{c}1.0 \\
(0.5-2.7) \\
1.0 \\
(0.8-1.5)\end{array}$ & $\begin{array}{c}0.8 \\
(0.6-1.4) \\
0.7 \\
(0.6 \cdot 0.8)\end{array}$ & $\begin{array}{c}- \\
(0.6 \cdot 1.2)\end{array}$ & $\begin{array}{c}0.5 \\
(0.4-1.0) \\
0.6 \\
(0.5-1.0)\end{array}$ \\
\hline M. atuerale (in $\mathrm{cm}$ ) & AS & - & - & - & 3.6 & $\begin{array}{c}3.2 \\
(2.1-4.8) \\
4.6 \\
(3.2-6.0)\end{array}$ & $\begin{array}{c}3.7 \\
(2.2-5.0) \\
4.6\end{array}$ & $\begin{array}{c}4.0 \\
(3.4 .5 .0) \\
2.8 \\
(2.0-4.5)\end{array}$ & $\begin{array}{c}3.9 \\
(3.0 .4 .8) \\
4.0 \\
(1.1 .6 .0)\end{array}$ \\
\hline M. Lar $($ in $\mathrm{cm})$ & $\begin{array}{l}\text { AF } \\
\text { AS }\end{array}$ & $\begin{array}{l}- \\
-\end{array}$ & $\begin{array}{c}4.2 \\
(2.3-6.0\end{array}$ & $\left(\begin{array}{l}5.0 \\
(4.2 .6 .0) \\
7.5\end{array}\right.$ & $\begin{array}{c}3.6 \\
(3,0.5,0) \\
4.9 \\
(2,7-8,0)\end{array}$ & $(1.5 .9 .5)$ & $\begin{array}{l}2.6 \\
\{1,5 \cdot 3.0\}\end{array}$ & $\begin{array}{c}7.5 \\
3.9 \\
(1.8-7.0)\end{array}$ & $(1.1-1.5)$ \\
\hline
\end{tabular}

Maciolek 1978, Haynes 1985) have also commented on how human activities can affect the unique fauna of island streams.

\subsubsection{Thiarid and other snails}

The second family of snails collected in the Opunohu, the Thiaridae ( = Melaniidae), had two species represented (Table 2). Although members of this family are parthenogenic and viviparous, a few species may produce veliger larvae instead of fully formed snails (Morrison 1954). In the Opunohu, we have observed that $M$. tuberculata is viviparous. Consequently, the size differences found for $N$. canalis over an elevational gradient in the Opunohu were not found for $M$. tuberculata ; the smallest size class of snails ( $1 \mathrm{~mm}$ opercular width) and the largest size class $(7 \mathrm{~mm})$ occurred at both upstream and downstream sites (Table 4). M. tuberculata was the only species of snail found at every site examined in the Opunohu.

Haynes (1985) reported that $\boldsymbol{M}$. tuberculata was also the most widespread snail found in a Fijian stream. Starmühlner (1982) found it from the headwaters to the mouth of a south Andaman Island stream. Marquet $(1987,1988)$ found it from $0-800 \mathrm{~m}$ in his survey of Tahiti and Moorea. Dudgeon (1986) described the life history of this species in Hong Kong, and he reported marked similarity with life history features in a Malaysian stream population. Dudgeon (1986) views this species as an opportunist or « fugitive " species, which because of its parthenogenicity and high productivity, is able to numerically dominate certan habitats. Because $M$. tuberculata is a common intermediate host of digenetic trematodes (e.g. Dasmahapatra et al. 1982), the body of published literature on $\boldsymbol{M}$. tuberculata is larger than for any other member of the Opunohu fauna. $M$. tuberculata is widely distributed, from the north and west coasts of Africa to China and the Pacific Islands (Haynes 1984).

Two individuals of a second species of Thiaridae, T. granifera (= Terebia granifera), were also collected. In other streams this species reportedly lives on sand and mud substrates with higher population densities in pool than riffle habitats (Starmühlner 1976). In the Opunohu, it was only found in the two most downstream sites, MRIV and MPIV. In his survey of Tahiti and Moorea, Marquet found it 
from 0-10 m elevation. It also occurs in parts of Asia and other Pacific Islands (Starmühlner 1976).

Empty shells of terrestrial snails were often encountered in collections, particularly at heavily shaded sites. For example, shells of the large terrestrial snail Euglandina rosea Ferussac commonly occur in crevices where debris collects. E. rosea was introduced into Moorea in 1977 to control the previously introduced giant African snail Achatina fulica Bowdich; seven species of Partula snails endemic to Moorea became extinct as a result of the Euglandina introduction (Murray et al, 1988). In Hawaii, E. rosea enters shallow water and preys on aquatic snails (Howarth 1991). Could this predatory snail affect the distribution of $N$. canalis and other snails at the upstream, shallow-water sites of the Opunohy ?

\subsection{Crustacea}

The crustacean fauna of the Opunohu consists of shrimps, crabs, amphipods, and isopods (Table 2). Of these, only shrimp were widely distributed and commonly collected. We collected two families of shrimp in the Opunohu: Atyidae and Palaemonidae.

\subsubsection{Atyid shrimp}

The atyids collected consisted of two species : $A$. pilipes and $C$. weberi. In the Opunohu, $A$. pilipes was found at all sites, and during both seasons (except for site EIII in austral spring). This distribution covers a broad elevational range : from 2 to $335 \mathrm{~m}$. Marquet $(1987,1988)$ reported collecting it from 10 to $800 \mathrm{~m}$ in his survey of Tahiti and Moorea. This species is widely distributed : from the Philippines and Lesser Sunda Islands east ward through the south Pacific to the Marquesas Islands (Chace 1983 ) and the eastern Caroline Islands (Maciolek \& Ford 1987).

C. weberi was also found at every sampling site (an altitudinal distribution from 2 to $335 \mathrm{~m}$ ) and during both seasons (except site MRIV in austral fall) ; Marquet $(1987,1988)$ found it on Tahiti and Moorea from 10 to $800 \mathrm{~m}$ elevation. C. weberi occurs from Indonesia to Fiji, Tahiti, and the Marquesas (Edmondson 1935, Adamson 1935) and the eastern Caroline Islands (Maciolek \& Ford 1987).

Both $A$. pilipes and $C$. weberi are thought to be diadromous, having migrations to and from the ocean as was described for the neritid snails. Since both species are found from the headwaters to the mouth of the Opunohu, we would expect to find size distribution differences along the stream, which reflects their upstream migration. Smaller specimens of atyids were found in the downstream sites of the Opunohu catchment (Table 4) : the range of body lengths of $A$. pilipes collected at sites OIV, MRIV, and MPIV was from $0.5 \mathrm{~cm}$ to $1.5 \mathrm{~cm}$. whereas the range at upstream sites was $0.5-3.4 \mathrm{~cm}$; for $C$. weberi the size range for the lower three sites was $0.4 \mathrm{~cm}$ to $1.4 \mathrm{~cm}$, whereas for the upper sites it was $0.5 \mathrm{~cm}$ to $2.8 \mathrm{~cm}$. Felgenhauer \& Abele (1983) have observed that larger animals of another atyid species, Atya innocus (Herbst), were found at higher elevations. Adults of $A$. innocus release zoea larvae that move downstream to the ocean, where further development takes place and, like neritid snails, mass upstream migrations of juvenile $A$. innocus occur (Felgenhauer \& Abel 1983).

Our studies in the Opunohu indicate that cheliped morphology and, consequently, differences in feeding methods are the main factors determining the microdistribution of $A$. pilipes and $C$. weberi. This can be seen in the differences in numbers and sizes of shrimp collected in leaf packs, D-frame nets, and riffle samples at the same stream site. For example, in the austral fall collection at site EIII, 59 small (i size $0.8 \mathrm{~cm}$ ) $C$. weberi were collected from leaf packs and nine large $C$. weberi $(1.4-1.8 \mathrm{~cm})$ were collected in D-frame collections, but none were found in shallow-run collections. In contrast, $A$. pilipes was absent in leaf packs, but 35 large specimens $(1.2-3.4 \mathrm{~cm})$ were collected in the D-frame collection and 54 others $(0.8-3.3 \mathrm{~cm})$ were collected in the shallow-run collections. Similarly at site OIlA, $C$. weberi were collected in leaf packs and D-frame samples, while $A$. pilipes were collected only in the shallow-run collections. We postulate that $A$. pilipes is filter feeding in faster flowing habitats (i.e. in the shallow-run habitats), while $C$. weberi are scraping and sweeping detritus within and on leaf surfaces and also in other microhabitats on the stream channel bed.

All members of the genera Atyoida and Caridina are characterized by the presence of setae on the distal ends of the first and second pereiopods ; the set ae may be used for passive filter-feeding or they may be modified with " teeth " for scraping and sweeping rocks for algae and other food and detritus (Fryer 1977, Hobbs \& Hart 1982, Chace 1983, 
Felgenhauer \& Abele 1983). The chelipeds in the Atyidae are trimorphic : the atyoid type of cheliped is used principally for filter feeding ; the ortmannoid type for filter feeding and sweeping the substrate; and the caridinoid type for scraping but not filter feeding (Chace 1983). A pilipes has a dimorphic cheliped structure, with atyoid and ortmannoidtype chelipeds for filtering; $C$. weberi has the caridinoid-type cheliped. Other species of Caridina are " habitual " scraping and sweeping organisms that feed while moving forward or remaining stationary (Fryer 1960).

A microdistributional pattern similar to that found in the Opunohu has been described by Felgenhauer \& Abele (1983) for two atyid shrimp in Panamanian streams. Two congeners, $A$. innocus and Atya margaritacea A. Milne Edwards, occur together in many streams. $A$. innocus is a scraper ; A. margaritacea feeds by passive filtration. A. margaritacea is limited to a single habitat - the fastest flowing areas of the stream. A. innocus can also occupy this same habitat but when they are together in either the field or laboratory, $A$. margaritacea will displace $A$. innocus. $A$. innocus is found in more diverse habitats and streams than $A$, margaritacea and is more common over the geographic range of the two species.

At several upstream sites, shallow-run collections were made in what appeared to be ideal Simulium habitats ; however, these yielded no black fly larvae but large numbers of $A$. pilipes shrimp. From this, we wondered whether direct interactions may be occurring between these taxa that could lead to displacement of black flies by shrimp. Observations made at the Afareaitu Cascade on Moorea in austral fall 1988 indicated that $A$. pilipes were actively displacing black fly larvae from the vertical cascade surface, apparently competing (by interference competition) for filtering sites. This topic deserves further study.

We do not know the reproductive cycles of Atyidae shrimp in Opunohu stream, but some scasonality is apparent. In our austral fall collections, gravid Atyidae female shrimp were collected at the following sites : OI - none; OII - $A$. pilipes and $C$. weberi; OIIA - A. pilipes; OIIB - A. pilipes and C. weberi; EIII - A. pilipes ; OIII - C. weberi; MRIV - none ; MPIV - $C$. weberi. In contrast in austral spring, gravid females of $A$. pilipes were only found at site MRIV; gravid females of $C$, weberi were found at sites OII, OIIA, OIIB, and EllI.

\subsubsection{Palaemonid shrimp}

The second shrimp family collected in the Opunohu, the Palaemonidae, consisted of two species of Macrobrachium. This genus is found throughout the tropics and several subtropical locations (Holthuis 1950,1980$)$; Holthuis (1950) provides a complete taxonomic discussion of the Palaemonidae. Macrobrachium are found in both marine and freshwater habitats. Some species complete their life cycle entirely in freshwater, other species never leave the marine environment, and still other species are diadromous (e.g. Kubota 1972, Holthius 1980).

Macrobrachium lar was collected at sites OII and all downstream sites, from 2 to $213 \mathrm{~m}$ elevation ; Macrobrachium australe was collected at sites OIIB and below, from 2 to $12 \mathrm{~m}$ elevation. Marquet (1987, 1988) collected $M$. lar at elevations from $0-800 \mathrm{~m}$ and $M$, australe from $0-20 \mathrm{~m}$ elevation in his survey of Tahiti and Moorea.

Using an electroshocker, Marquet $(1987,1988)$ collected five species of Macrobrachium from the Opunohu; besides $M$. lar and $M$. australe, he collected specimens of $M$. latimanus (V. Martens), $M$. aemulum (Nobili), and an undescribed species of Macrobrachium. These latter three species were not collected during our study, perhaps because we used different collecting methods ; in Hawaii, Maciolek \& Ford (1980) found electroshocking (the technique used by Marquet) the most efficient way to collect M. lar.

Macrobrachium lar is the most common IndoWest Pacific species of palaemonid shrimp. It is found in southern and east Africa, through the Malay Archipelago and the south China Sea to the Marquesas Islands and Tuamotus (Holthuis 1950 \& 1980, Maciolek 1972). In the late 1950's and early $1960^{\circ}$ 's it was introduced to Hawaii ; $M$. lar is a very successful « invader » species because of its large size, aggressiveness, and predaceous-omnivorous diet (Maciolek 1972). M. lar is a nocturnal, omnivorous bottom scavenger (Kubota 1972).

Macrobrachium australe is found in the IndoWest Pacific from Seychelles and Madagascar to the Malay Archipelago and through the high islands of the South Pacific to the Marquesas Islands (Holthuis $1950 \& 1980)$. $M$. australe is probably a predatoromnivore like $M$. lar. 
Macrobrachium lar and $M$. australe are both diadromous. Holthuis (1980) reports that $M$. australe larval stages develop in salt water. Kubota (1972) and Holthuis (1980) report that the young $M$. lar are also found in saline or estuarine conditions. In Hawaii, $M$. lar larvae are flushed downstream to the ocean where they undergo 11 molts in 5.7 weeks; juveniles return to a stream and begin an upstream migration when they are about $1 \mathrm{~cm}$ long (Maciolek 1972).

The size distribution of $M$. lar and $M$. australe along a stream elevational gradient has a similar pattern to that found for atyid shrimp in the Opunohu (Table 4). Smallest specimens (1.1-1.5 $\mathrm{cm}$ in length) of $M$. Iar were found at site MPIV; individuals as large as $8 \mathrm{~cm}$ were found at more upstream sites. The smallest $M$. austrate were found at site MPIV $(1.1 \mathrm{~cm})$; however, large individuals $(6.0 \mathrm{~cm})$ were found there as well.

Gravid Macrobrachilum females were observed at the following sites in austral fatl : OI - none ; OII - none ; OIIA - none ; OIIB - $M$. australe ; EIII $M$. Iar ; OIII - M. australe; MRIV - $M$. australe ; MPIV - $M$. australe. In austral spring gravid females were observed at : OIIB - M. lar and $M$. australe ; and OIII - M. australe. Marquet (1988) examined the proportion of females « ovigères " of $\boldsymbol{M}$. lar in the Opunohu and found the lowest proportions $(30 \%)$ in March, $67 \%$ in April, - $45 \%$ in May and June, and the highest proportion in December ; however site(s) studied was not indicated.

The distribution of Macrobrachium in the lower Opunuhu may be influenced somewhat by predaceous eels (fishing is prohibited in this catchment). Marquet \& Lamarque (1986) found that Macrobrachium was the major food item of freshwater eels that occur in the Opunohu.

\subsubsection{Amphipod sandhoppers}

The amphipod $A$. pacificus was found at site OIIA during both seasons and at several of the Opunohu sites sampled in austral spring (Table 2). This species of sandhopper, like other terrestrial taltrids, apparently inhabits the forest-litter leaf mold ; it was collected most commonly in leaf packs (and in Dframe collections, which could have disrupted leaf packs). Hurley (1959) gives a detailed account of the ecology of sandhoppers ; this species is also known from Australia, the Marquesas Islands, Norfork Istands, and the United States.

3.3.4. The Oniscid isopods collected in the Opunohu included Lobodillo hebridarum (Verhoeff) and Sphaerillo (Xestodillo) marquesarum Jackson in the family Armadillidae, and Pseudosetaphora truncata (Dollfus) and a new genus and species in the family Philosciidae.

\subsection{Insecta}

Aquatic insects studied in Polynesia were included in results of the 1928-1929 Pacific Entomological Survey conducted by the Bernice P. Bishop Museum (located in Honolulu, Hawaii), which provided descriptions of Odonata (Needham 1935), Hemiptera (Lundblad 1935), and Diptera (Edwards 1935 a \& 1935 b, Alexander 1935) from Tahiti. Most aquatic insect research in the past decade has dealt with two of the ten species of Polynesian mosquitoes, Aedes polynesiensis Marks and Aedes aegypti (Linn.), which are vectors of filariasis and dengue on Moorea and other Polynesian islands (Bourgeois 1980).

Five insect orders are represented in the Opunohu (Table 2). Insects comprised about one-half of the macroinvertebrate species richness of the Opunohu, and more insect taxa were collected in the upstream sites. In comparing our results with those of other island stream studies, insect dominance of faunal richness seems to be related to the distance of the island from a mainland. For example, in studies of Caribbean Island streams, which are closer to a continent, estimates of richness were mostly based on aquatic insects (e.g. Hynes 1971, Harrison \& Rankin 1976). In contrast in Pacific Island streams, which are more isolated than Caribbean streams, Haynes (1987) found insects comprising from onequarter to two-thirds of species richness (depending on season) and Maciolek \& Ford (1987) found that insects comprised about one-fourth of the macroinvertebrate taxa collected.

\subsubsection{Odonata}

Nymphs of the damselfly Pacificagrion were found at most stations in the Opunohu. At a given site and season, nymphs ranged in length from 2 to $12 \mathrm{~mm}$, suggesting a multiple cohort pattern. Several early instars of a libellulid dragonfly were found in austral spring collections. 


\subsubsection{Diptera}

Several Diptera families were found but the Chironomidae and Simuliidae were the two most commonly collected. One or more species of Chironomidae was found at each site. All specimens of the Chironomidae were small (1-3 mm), a feature that makes dispersal useful (e.g. Kramer et al. 1973). We have not been successful in rearing chironomid larvae to adults for taxonomic associations, but at least five species of midges are present in the Opunohu (Table 2).

Craig (1987 b) recognized fourteen species of Simuliidae in the Society Islands; all black flies found in French Polynesia are endemic. Collections associated with this study now show that many Tahitian simuliid species are also on Moorea, as are some additional undescribed taxa. In addition, S. opunohuense is likely to be a synonym of $S$. lotii, and larvae of $S$. castaneum and $S$. cataractarum on Moorea show character differences from their types and may be new species.

At least five simuliid species occur in the Opunohu ; $S$. lotii is the most widespread, occurring at six of eight collection sites. This species is widespread on Tahiti and Moorea, and occurs with $S$. tahitiense, $S$. exasperans and $S$. oviceps in shaded, larger rivers and streams. There is a tendency for $S$. lotii larvae to be on stream vegetation (Schroder 1985).

Three black fly species are restricted to a single site in the Opunohu : $S$. cataractum, $S$. oviceps, and larvae that are either $S$. tahitiense or $S$. exasperans. $S$. cataractarum is strictly a madicolous species that is found only at site OI. At times it forms large populations, presumably using as a food source the high seston loads found in the cascade (see below). Schröder $(1985,1988)$ noted that $S$. cataractarum larvae show lower selectivity for small algae than do larvae of $S$. tahitiense. Larvae of $S$. cataractarum have countercolored body pigmentation, i.e. the dorsal surface is much darker than the pale ventral surface. Since these larvae occur in a madicolous habitat (water film $<2 \mathrm{~mm}$ thick), they do not twist the body to present their labral fans to the flow. Perhaps countercoloring provides protection from the intense solar radiation encountered in these habitats.

$S$. oviceps was only found at site OII but this species is very common on the island of Tahiti, where it occurs sympatrically with $S$. tahitiense in most of its habitats. S. oviceps has been the most studied of all Tahitian simuliid larvae because of its highly reduced labral fans (Dumbleton 1962, Davies 1974, Craig 1974 \& 1975, Schröder 1987). Craig (1975) suggested that $S$. oviceps larvae were browsers because of the presence of volcanic glass particles in their guts ; this was corroborated by observations on feeding behavior (Craig 1977). Schröder (1985) found a higher proportion of ingested detritus particles in $S$. oviceps larvae than in coexisting $S$. tahitiense larvae. In larger rivers, larvae of $S$. oviceps tend to be found around the outside of dense aggregations of $S$. tahitiense, which are normally found under large rocks in rapid currents. Elsewhere, $S$. oviceps larvae and pupae can be found in small depressions in the volcanic cascades, or occasionally on filamentous algae. Although nowhere nearly as abundant as larvae of $S$. tahitiense, larvae of $S$. oviceps can be numerous and form large monospecific groups.

Larvae of what is either $S$. rahitiense or $S$. exasperans were found at site OIl in austral fall. S. tahitiense is the most widespread black fly species in Tahitian streams. Its larvae are found mainly in the larger rivers, in dense aggregations under large boulders in strong flow. Large populations often occur where terrestrial vegetation trails in high-velocity water. Schröder (1985) provides details of the feeding behavior of $S$. tahitiense larvae. The adults of this species can form dense swarms around humans and cause considerable nuisance, although they (like other Tahitian simuliids) do not bite. Throughout Tahiti and Moorea, larvae of $S$. exasperans are usually found on vegetation in well shaded, larger streams. In some places they form almost the complete black fly guild; other times they are found with $S$. lotii, S. oviceps, and $S$. tahitiense.

The other black fly species in the Opunohu, $S$. malardei, occurs on trailing vegetation in small, densely shaded streams and trickles of water. It was found at four sites in the Opunohu and in high densities at upstream sites. This species or forms related to it are also found on Tahiti, Raiatea, Huahine, and Bora Bora.

Little is known about the ecology of Polynesian simuliids. Black fly larvae are typically thought of as filter feeders, using two elegant labral fans to capture seston. However, in the Society Islands, larvae 
of some species of the oviceps-group have highly reduced labral fans and some species appear to lack them entirely. Larvae of all species are associated with fast water $(>30 \mathrm{~cm} / \mathrm{s})$; details on filterfeeding selectivity of $S$. cataractarum and $S$. tahitiense have been reported by Schröder (1988).

There is a strong correlation between population density of simuliid larvae and available seston ; for example, very large numbers can be associated with lake outlets (e.g. Wotton 1979). Because simuliid larvae can also feed by browsing and even by cannibalism (Currie \& Craig 1987) low seston levels are not necessarily a limiting factor, although nutrition is known to af fect longevity and fecundity of aduits (Colbo \& Porter 1979). In the Opunohu, larger simuliid populations are clearly associated with higher seston levels (see below).

In terms of life cycles of Polynesian simuliids, Klein \& al. (1983) reported that one generation of Simulium buissoni Edwards could be completed within 10 days in the Marquesas Islands, but no such studies have been done for the Society Islands. Extensive collections in Tahiti and Moorea suggest that some species may have distinct cohorts (because of the similarity in size of all larvae on a given date) in small, upst ream reaches but in the larger rivers there always seems to be a complete range of sizes and stages, indicating multivoltinism (Craig 1975). There is also some evidence of seasonality in species occurrence. Recent repeated collections from a cascade on Tahiti have shown completely different species occurring within two months. However, there is no such evidence for seasonality in species composition in the large rivers.

Of the other Diptera collected, the ephydrid $A$. cheesmanae was abundant in algal-moss samples at sites OI and OII. Larvae are found with many of the larger aggregations of $S$. tahitiense. Although larvae are extremely slow moving, there is a possibility that $A$, cheesmanae larvae are predaceous on simuliid larvae (Craig 1987 b).

\subsection{Other Fauna}

Several non-insect or non-crustacean arthropods were commonly collected in the Opunohu (Table 2). The oribatid mites collected in the algal-moss mats at sites $O I$ and in leaf packs and riffle samples at the other sites contained algae in their guts. The two species were not distinguished in the samples.
Hammer (1982) has discussed how moss-inhabiting oribatids have dispersed through the islands of this South Pacific.

The millipede $O$. gracilis was common at all sites examined in the Opunohu and submerged specimens were routinely collected in riffles, leaf packs, and shallow-water habitats; however, this species is really an accidental aquatic animal (H. Enghoff, pers. comm.). Other studies (e.g. Enghoff 1985, Adis 1986) have also reported that millipedes occupy aquatic habitats. This species is probably indigenous to East Asia but now occurs throughout the tropics, including the West Indies and many islands in the Atlantic and Pacific; it occupies a range of habitats, from hothouses to gardens to compost heaps (Blower 1985). Three other species of millipedes appeared occasionally in the Opunohu collections : Glyphiulus grnulatus (Gervais) (Sperostuptida : Cambalopsidae) - a widespread species on Pacific Islands; Siphonophora sp. (Siphonophorida: Siphonophoridae); and a species of the order Spirobolida (Enghoff, pers. comm.).

At least six species of oligochaetes occur in the Opunohu. Most genera of the Naididae are cosmopolitan (as are those of the Tubificidae) and most genera with a more tropical and/or southern distribution are naidids (Brinkhurst \& Jamieson 1971). The naidid $A$. inaequalis is known from southern Asia, Africa, South America and Australia ; A. pectinata is known from Asia and Africa ; $P$. menosi is known from Europe, Asia and Africa ; and $P$. proboscidea is known from South America, Africa, Asia, and Australia (Brinkhurst \& Jamieson 1971).

The nematode Mesodorylaimus was collected at two sites in the Opunohu, site EIII and MPIV, in austral fall. This species is predaceous (Poinar, pers. comm.).

\section{The Island Stream Ecosystem}

Maciolek \& Ford (1987) recently characterized Pacific volcanic (or high) island streams as follows : drainages are small as a consequence of island size ; geochemical in fluence (for basaltic terrane) leads to waters of low mineral content and similar ionic composition; heavily vegetated watersheds contribute observable organic solutes when humus is released ; lush riparian vegetation is a constant source of particulate organic matter ; temperatures are stenothermally warm, and bedrock, boulders, and cobbles 
dominate the substrata; and that while the above factors provide a relatively constant environment, variable discharge may have considerable effects. These characteristics generally conform to what we have observed in the Opunohu. However, certain features of the headwater habitats and the stream mouth-estuarine habitat deserve special mention.

\section{1. Headwater Habitats}

The Cascade (site OI) is typical of headwater strearns on Moorea ; it arises from springs and seepages high $(>300 \mathrm{~m}$ ) on the vertical walls of volcanic remains. We visited several of these habitats on Moorea and Tahiti - typically the water flows in thin sheets over filamentous algae and moss on black basaltic rocks, and then forms a small plunge pool at the base of the cascade. Using energy dispersive $\mathrm{X}$-ray analysis, we found that the rock that comprises site OI cascade is rich in calcium and magnesium. The Opunohu cascade is not shaded by vegetation and receives direct sunlight for most of the day. Water temperatures at this site regularly reach $30^{\circ} \mathrm{C}$, and the lowest temperature recorded over a two-week period in austral fall was $21^{\circ} \mathrm{C}$.

Conductivity in the cascade habitat is low, $\sim 30{ }_{\mu} \mathrm{S} / \mathrm{cm}$, which is not unexpected given the rapid runoff from the frequent rains. The $\mathrm{pH}$ is generally higher than 9.0 at site $\mathrm{OI}$ and in other cascades we have examined, i.e. the Afareaitu Cascade on Moorea where $\mathrm{pH}$ values are as high as 10.2 . In poorly buffered waters such as found in these habitats, high $\mathrm{pH}$ conditions result from depletion of carbon dioxide by the primary production of the vegetation (e.g. Ruttner 1974). The higher primary production that occurs at site $\mathrm{Ol}$ can be seen in the levels of seston (i.e. particles larger than $0.45 \mu$ ) found in the cascade water (a maximum of $3.4 \mathrm{mg} / 1$ ) compared to that found in the lower reaches (generally well below $2.0 \mathrm{mg} / \mathrm{l}$ ). Seston from the cascade site was mainly composed of diatoms, while that of the sites in the lower reaches contained more detrital material.

These madicolous habitats created by the thin, vertical sheets of water flowing down the cascade support a unique fauna of black fly species both in Moorea and Tahiti. For example, $S$. cataractarum is restricted to such habitats, as are some rarer species of the oviceps-group (Craig $1987 \mathrm{~b}$ ).

\subsection{Estuarine Habitats}

Below site MPIV, the streams flowing through the Mouapu and Mouaroa Valleys converge with the main branch of the Opunohu and flow into the oceanic waters of the Opunohu Bay. As indicated above, early development of shrimp and neritid snails probably occurs in this estuary. In November 1989, we examined the fauna that occurs in the freshwaterestuarine transition zone. Here, in fresh water but well below the first well-defined riffle of any of three converging streams (from sites OIIl, MRIV, MPIV) the neritid snail Neritina auriculata Lamarck was collected. Snails $1-2 \mathrm{~cm}$ long were collected in this freshwater habitat, oftentimes on rocks containing empty oyster shells and remains of other typically marine species.

The confinement of $\mathcal{N}$. auriculata to freshwater areas near the estuary could reflect the low motility of adults, or perhaps their inability to cross the hydraulic barrier present at the first riffle. We do not think the latter is the case because we have found N. auriculata in riffle habitats that are located close (within $15 \mathrm{~m}$ ) to the ocean in a stream near Haapiti on Moorea. Oysters may occur in what are now $N$. aturiculata-freshwater habitats during low rainfall years, when saltwater intrusion from the bay extends the upstream estuarine habitat. Such fauna, however, would perish as increased rainfall advanced the freshwater boundary of the stream and lowered the salinity there.

\subsection{Macroinvertebrate Zonation Patterns on Island Streams and Continental Streams}

Although only first-through fourth-order sites occur in the Opunohu catchment before the stream enters the bay, Minshall (1988) has pointed out that this range of stream orders represents the practical extent of most catchment studies. Because of its proximity to the ocean, the data collected in this study allows us to examine one of the controversies raised by the River Continuum Concept (Vannote \& al. 1980). In that widely discussed paper, the authors proposed that maximum species diversity occurs in midreaches of rivers because of a spatial shift involving two vectors: richness of aquatic insects decreases in downstream reaches and richness of molluses and crustaceans decreases in unc tream reaches. This is based on the premises ula. . (1) insects evolved terrestrially and the maximum terrestrial-aquatic interface occurs in headwaters ; 
therefore, it is likely that the terrestrial-aquatic transition first occured in headwaters and aquatic insects then progressively moved downstream ; and (2) molluscs and crustaceans evolved in marine environments, gradually moved into rivers, and then to upstream reaches of lotic systems (Vannote $\&$ al. 1980).

This was one of the five tenets of the River Continuum Concept criticized by Statzner \& Higler (1985). They argued that diversity (which they interpreted using Shannon's Index) and distribution shifts of insects and of molluses and crustaceans that occurred at either similar or dissimilar rates would not be expected to produce the high biotic diversity in midreaches of streams.

In the Opunohu we can rephrase the original speculation of the River Continuum Concept to : Is richness of insects highest in headwaters, and richness of molluscs and crustaceans highest near the sea ? Collections in the Opunohu indicate that this is the case : insect richness was highest at the two upstream-most sites; and molluse and crustacean richness was highest at the downstream-most site (Table 2). Some species of insects are limited to the high gradient headwaters, whereas some species of molluscs and crustaceans are limited to the lower reaches (i.c. nearer the ocean) of the Opunohu.

Covich (1988) also reported that many tropical, lowland species of gastropod molluscs and decapod crustaceans colonize freshwater streams from nearshore marine and brackish-water habitats but that the richness of these non-insect migrants typically declines upstream, especially on islands ; in contrast, insect species richness is higher in the upper reaches on some Caribbean Island streams. We also reanalyzed the survey data of Kinzie \& Ford (1977) from a Hawaiian stream : in upstream reaches insect richness exceeded molluscan and crustacean richness ; in downstream reaches richness of the latter groups was higher. While this tenet of the River Continuum Concept seems to apply to Pacific island streams, extrapolation of this reasoning from island to continental streams is difficult. For example, highest richness may occur in midreaches of continental rivers for reasons as simple as that this is where the greatest microhabitat and food-source diversity occurs.

Finally, does the restricted distribution of most of the gastropod molluscs to the downstream-most reaches of the Opunohu reflect a survival advantage for the next generation that must return to the sea to complete development, or physical limitations to upstream migration (e.g. riffles and waterfalls) that are most likely related to individual species responses to hydraulic stresses (Statzner \& al. 1988)? Aquarium studies indicated that a species of snail restricted to the lower-most site ( $N$. turrita) had the greatest motility ; the most sedentary snail species in these aquaria ( $S$. porcellana) reportedly travelled great distances in other studies. Fascinating autecology studies, comparisons among aspects of temperate, tropical, continental, and island strearn communities, and many other interesting questions await further studies of oceanic island streams. In addition, the Opunohu catchment offers a major advantage for further study : the logistical benefit of having two biological research stations (see acknowledgments) located nearby.

\section{Acknowledgments}

For assistance throughout this study we thank B. Benis-Steger, W. Loher, and R. Steger of the Richard B. Gump University of California South Pacific Biological Research Station (Pao Pao, Moorea), and R. Galzin, G. Richard, and B. Satvat of the Centre de l'Environnement de Moorea, Muséum d'Histoire Naturelle et Ecole Pratique des Hautes Etudes (Papeitoa, Moorea). F. de Szalay, C. Haigh, and G. Shigomoto provided field and laboratory assistance. V. Behan-Pelletier, E. Bergey, T. Bowman, D. Cadien, N. Connelly, J. Doyen, H. Engoff, L. Ferrington, R. Garrison, E. McElravy, G. Nostida, G. Poinar, J. Polhemus, J. Powell, F. Starmühlner and C. Yearsley assisted with identifications. G. Marquet provided an excellent baseline study of Moorea and Tahiti, and these collections were available for our use at the EPHE-Antenne Museum in Moorea. Funding for this project was provided by the College of Biological and Agricultural Sciences, Brigham Young University, Utah, and the Natural Science and Engineering Research Council of Canada, grant OGP A 5753 . We also acknowledge assistance from Institut Territorial de Recherches Medicales Louis Malardé.

\section{References}

Adamson (A.M.). 1935. - Nonl-masine invertebrate fauna of the Marquesas (exclusive of insects). Occ. Pap. Bernice $P$. Bishop Mus., 11 (3) : 1-19.

Adis (J.). 1986. - An " aquatic " millipede from a Central Amazonian inundation forest. Oecologio, $68: 347-349$.

Alexander (C.P.). 1935. - New Tipulidae from the Society Islands. Bull. Bernice P. Bishop Mus., 113 : 53-56.

Blower (I.G.). 1985. - Millipedes. Synopses Br. Fauna, 35, 1-242.

Bourgeois (B.). 1980. - Les moustiques de Polynésie française. Bull. Nat. Polynésie française, $7:$ 1-20.

Bourne (G.C.). 1908. - Contribution to the morphology of the group Neritacea of aspidobranch gastropods. Part 1. Neritidae. Proc. zool. Soc. Lond. 1908: 810-887.

Brinkhurst (R.O.) \& Jamieson (B.G.M.). 1971. - Aquatic Oligochaeta of the World. Edinburgh, Scotland, Oliver and Boyd. $860 \mathrm{p}$. 
Carlquist (S.). 1974. - Island Biology. New York, Columbia University Press. 660 p.

Chace (F.A., Jr.). 1983, - The Atya-like shrimps of the IndoPacific region (Decapoda : Atyidae). Smithson. Contr. Zool., $\mathrm{N}^{\circ} 384,54 \mathrm{p}$.

Colbo (M.H.) \& Porter (G.N.). 1979. - Effects of food supply on the life history of Simuliidae (Diptera). Can. J. Zool., 57 : 301-306.

Covich (A.P.). 1988. - Geographical and historical comparisons of neotropical streams : biotic diversity and detrital processing in highly variable habitats. $J . N$. Am. Benth. Soc., $7: 361-386$.

Craig (D.A.). 1974. - The labrum and cephalic fans of larva! Simuliidae (Diptera: Nematocera). Can. J. Zool., 52 : 133-159.

Craig (D.A.). 1975. - THe larvae of Tahitian Simuliidae (Diptera : Nematocera). J. Med. Ent., Honolu/u, 12 : 463-476.

Craig (D.A.). 1977. - Mouthparts and feeding behaviour of Tahitian larval Simuliidae (Diptera : Nematocera). Quaest. ent., $13:$ 195-218.

Craig (D.A.). 1983, - Phylogenetic problems in Polynesian Simuliidae (Diptera : Culicomorpha) : a progress report. GeoJournal, $7.6: 533-54$.

Craig (D.A.). 1987 a. - Some of what you should know about water. Bull. N.Am. Benth. Soc., 4 (2) : 178-182.

Craig (D.A.). 1987 b. - A taxonomic account of the black flies (Diptera : Simuliidae) of the Society Islands-Tahiti, Moorea and Raiatea. Quaest. ent., $23: 372-429$.

Currie (D.C.) \& Craig (D.A.) . 1987. - Feeding strategies of larval black flies. 155-170. In K.C. Kim and R.W. Merritt (Eds.). Black Flies : Ecology, Population management and Annotated World List. University Park, Pennsylvania, Penn State University Press. $528 \mathrm{p}$.

DasMahapatra (S.), DasGupta (B.) \& Choudhury (A.). 1982. Susceptibility of freshwater gastropods to larval trematode infection in west Bengal (India). Malacologia, $22: 35-38$.

Davies (L.). 1974. - Evolution of larval head-fans in Simuliidae (Diptera) as inferred from the structure and biology of Crozetia crozetensis (Womersley) compared with other genera. Zool. J. Linn. Soc., $55: 193-224$.

Dudgeon (D.). 1986. - The life cycle, population dynamics and productivity of Melanoides tuberculata (Müller, 1774) (Gastropoda : Prosobranchia : Thiaridae) in Hong Kong. J. Zool., Lond. (A.), $208: 37-53$.

Dumbleton (L.J.) 1962, - Aberrant head-structure in larval Simuliidae (Diptera). Pacif. Insects, $4: 77-86$.

Edmondson (C.H.). 1935, - Atyidae of southern Polynesia. Occ. Pap. Bernice P. Bishop Mus., 11 (3): 1-19.

Edwards (F.W.). 1935 a. - Some Tahitian Mycetophilidae and Chironomidae. Bull. Bernice P. Bishop Mus., 113 : 85-86.

Edwards (F.W.). 1935 b. - Tahitian Simuliidae. Bull. Bernice P. Bishop Mus., $113: 35-38$.

Enghoff (H.). 1985. - Modified mouthparts in a hydrophilous cave millepedes (Diplopoda). Bijdr. Dierk., $55: 67-77$.

Felgenhauer (B.E.) \& Abelle (L.G.). 1983. - Ultrastructure and functional morphology of feeding and associated appendages in the tropical fresh-water shrimp Atya innocous (Herbst) with notes on its ecology. $J$. Crust. Biol., $3: 336-363$.

Ford (J.1.). 1979. - Biology of a Hawaiian fluvial gastropod Neritina granosa Sowerby (Prosoùranchia : Neritidae). M.S. Thesis, University of Hawaii. 94 p.
Ford (J.I.) \& Kinzie III (R.A.). 1982, - Life crawls upstream. Nat. Hist., $91: 61-66$.

Fryer (G.). 1960. - The feeding mechanism of some atyid prawns of the genus Caridina. Trans. R. Soc. Edin., $64: 217-244$.

Fryer (G.. 1977. - Studies on the functional morphology and ecology of the atyid prawns of Dominica. Phil. Trans. R. Soc. (B.), $277: 57-129$

Gabrie (C.) \& Salvat (B.). 1985. - General features of French Polynesian Islands and their coral seefs, 1-16. In B. DeLeSalle. R. Galzin and B. Salvat (Eds.). Vol. 1. French Polynesian Coral Reefs. Fifth International Coral Reef Congress, Tahiti, 27 May-1 June 1985. Moorea, French Polynesia, Antenne Museum-EPHE. 486 p.

Galzin (R.) \& Pointier (J.P.). 1985. - Moorea Island, Society Archipelago. 73-102. In B. DeLeSalle, R. Galzin and B. Salvat (Eds.). Vol. 1. French Polynesian Coral Reefs. Fifth International Coral Reef Congress, Tahiti, 27 May-1 June 1985. Moorea, French Polynesia, Antenne Museum-EPHE. 486 p.

Grant (P.). 1986. - Ecology and Evolution of Darwin's Finches. Princeton University Press, New Jersey, 458 p.

Hammer (M.). 1982. - Spreading of oribatid mites (Acari) in the Southern Pacific. Z. zool. Syst. Evolut.forsch., 20 : 170-176.

Harrison (A.D.) \& Rankin (J.J.). 1976. - Hydrobiological studies of Eastern Lesser Antillean Islands. II. St. Vincent : Freshwater Fauna - its distribution, tropical river zonation and biogeography. Arch. Hydrobiol. Suppl., $50: 275-311$.

Haynes (A.). 1984. - Guide to the brackish and fresh water Gastropods of Fiji. Institute of Natural Resources, University of the South Pacific, Fiji. 39 p.

Haynes (A.). 1985. - The ecology and local distribution of nonmarine aquatic gastropods in Viti Levu, Fiji. Veliger, 28 : 204-210.

Haynes (A.). 1987. - Species richness, abundance and biomass of benthic invertebrates in a lowland tropical stream on the island of Viti Levu, Fiji. Arch. Hydrobiol., 110:451-459.

Haynes (A.). 1988. - Notes on the stream neritids (Gast ropoda ; Prosobranchia) of Oceania. Micronesica, $21: 93-102$.

Haynes (A.). 1990. - The numbers of Ereshwater gastropods on Pacific Islands and the Theory of Island Biogeography. Malacologia, $31: 237-248$.

Hobbs (H.H.) Jr. \& Hart (C.W.) Jr. 1982. - The shrimp Genus Atya (Decapoda : Atyidae). Smithson. Contr. Zool., No. 364. $143 \mathrm{p}$.

Holthuis (L.B.). 1950. - The Decopoda of the SibogaExpedition. Part $X$. The Palaemonidae Collected by the Siboga and Snellius Expeditions with Remarks on Other Species. Leiden, E. J. Brill. 268 p.

Holthuis (L.B.). 1980. - Shrimps \& Prawns of the World. An annotaded catalogue of species of interest to Fisheries. FAO Fisheries Synopsis, $125:$ XVI] + 271 [Volume 1 of FAO Species Catalogue].

Howarth (F.G.). 1991 _ - Environmental impacts of classical biological control. A. Rev. Ent., $36: 485-509$.

Hurley (D.E.). 1959. - Notes on the ecology and envirommental adaptations of the terrestrial Amphipoda. Pacif. Sci, 13 : 107.129.

Hynes (H.B.N.). 1970. - The Ecology of Running Water. Liverpool, Liverpool University Press. 555 p.

Hynes (H.B.N.). 1971. - Zonation of the invertebsate fauna in a West Indian stream. Hydrobiologia, $38: 1-8$, 
Kinzie (R.A.) III \& Ford (J.1.). 1977. - A limnological survey of lower Palikea arjd Pipíwai streams, Kipahulu, Maui. Technical Repon 17. Cooperative National Park Resources Study Unit. Dept of Botany, University of Hawaii at Manoa. $44 \mathrm{p}$.

Klein (J.M.), Rivière (F.) \& Séchan (Y.). 1983. - Recherches d'entomologie médicale aux Iles Marquises en 1982. Notes et Doc. Hyg. et S. Publ., ORSTOM. $7: 1-81$.

Kramer (C.L.), Wartell (J.) \& Holzapfel (P.). 1973. - Surface level trapping of air biota on the Pacific Ocean. Agric. Mefeorol., $12: 49-64$.

Kubota (W.). 1972, - The biology of an introduced prawn Macrobrachium lar (Fabricius) in Kahana Stream. M.S. Thesis, University of Hawaii. $185 \mathrm{p}$.

Lamberti (G.A.) \& Moore (J.W.). 1984. - Aquatic insects as primary consumers. 164-195. In V.H. Resh and D.M. Rosenberg (Eds.). The Ecology of Aquatic Insects. New York, Praeger Publishers. 625 p.

Lundblad (O.). 1935. - Aquatic and semiaquatic heteroptera of Tahiti. Bull. Bernice P. Bishop Mus., $113:$ 121-126.

MacArthur (R.H.) \& Wilson (E.O.). 1967. - The theory of island biogeography. Monographs in Population Biology 1. Princeton, New Jersey, Princeton University Press. 203 p.

Maciolek (J.A.). 1972. - Macrobrachium lar as a culture prawn in the tropical insular Pacific. W. Assoc. Stote Game Fish Comm. Proc., 52 : 550-558.

Maciolek (J.A.). 1975. - Limnological ecosystems and Hawaii's preservational planning. Verh. int. Verein. theor. angew. Limnol., $19: 1461-1467$.

Maciolck (J.A.). 1978. - Shell character and habitat of nonmarine Hawaiian neritid snails. Micronesica, 14 : 209-214.

Maciolek (J.A.) \& Ford (J.I.). 1980. - Electroshocking in tropical insular streams. Prog. Fish. Cult., 42 : 57-58.

Maciolek (J.A.) \& Ford (J.I.). 1987. - Macrofauna and environment of the Nanpil-Kiepw River, Ponape, Eastern Caroline Islands. Bull. mar. Sci., $41:$ 463-632.

Marquet (G.). 1987. - Périlogie des anguilles de Tahiti-Moorea en Polynésie Française. Diplôme de l'Ecole Pratique des Hau. les Etudes. Paris. 150 p.

Marquet (G.). 1988, - Les eaux intérieures de la Polynésie Française. Principales caractéristiques physiques, chimiques et biologiques. Thèse de Doctorat de l'Universite Paris VI. 233 p.

Marquet (G.) \& Lamarque (P.). 1986. - Acquisitions récentes sur la biologie des anguilles de Tahiti et de Moorea (Polynésie Française) : A. marmorata, A. megastama, A, obscura. Vie Milieu, $36: 311-315$.

Marquet (G.) \& Lamarque (P.). 1987. - Prospecting the fauna in the freshwaters of Tahiti and Moorea (French Polynesia). 86. In Abstracts. $X X I I I$ Congress of the International Association of Theoretical and Applied Limnology. Hamifton, New Zealand.

Minshall (G.W.). 1988. - Stream ecosystem theory ; a global perspective. J. N. Am. Benth. Soc,. $7: 263-288$.

Minshall (G.W.), Andrews (D.A.) \& Manuel-Faler (C.Y.). 1983. - Application of island biogeographic theory to st reams : macroinvertebrate recolonization of the Teton River, Idaho. In J.R. Barnes and G.W. Minshall (Eds.). Stream Ecology : Application and Testing of General Ecological Theory. New York, Plenum Press. $399 \mathrm{p}$.

Minshall (G.W.) \& Peterson (R.W.). 1985. - Towards a theory of macroinvertebrate community structure in stream ecosystems. Arch, Hydrobiol., 83 : 324-355.
Morrison (J.P.E.). 1954. - The relationships of old and new world melanians. Proc. U.S. ratn. Mus., $103: 357-393$.

Murray (J.), Murray (E.), Johnson (M.S.) \& Clarke (B.), 198 - The extinction of Partula on Moorea. Pacif. Sci, 42 $150-153$

Needham (J.G.). 1935. - Odonata from Tahiil. Bull. Bernice P. Bishop Mus, $113: 21-23$.

Pointier (J.P.). 1986. - Les Mollusques. 83-84. In B. Salvat (Ed.). Encyclopédie de la Polynésíe. Vol. 2. Flore et Faune Terresires. Papeete, Christian Gleizal/Multipress. 145 p.

Ruttner (F.). 1974. - Fundamentals of Limnology. 3rd Edition. Toronto, University of Toronto Press. $307 \mathrm{p}$.

Schneider (D.W.) \& Frost (T.M.). 1986. - Massive upstream migrations by a tropical freshwater neritid snail. Hydrobiologia, $137: 153-157$.

Schröder (P.). 1985. - Feeding biology of Tahitian blackfly larvae (Dipt. Simuliidae). Notes et Doc. Hyg. et S. Publ., ORSTOM, $11: 1-230$.

Schröder (P.). 1987. - Labral filter fans of blackfly larvae. Differences in fan area and fan ray number and the consequences for utilization and particle selection. Zool. Beitr., 31 : 365-394.

Schröder (P.). 1988. - Gut-passage, particle selection and ingestion of filter-feeding blackfly (Diptera : Simuliidae) larvae inhabiting a waterfall in Tahiti (French Polynesia). Aquatic Insects, 10:1-16.

St . Clair (1.L.) \& Rushforth (S.R.). 1977. - The diatom flora of the Goshen Warm Spring ponds and wet meadows, Goshen, Utah. Nova Hedwigia, $28: 353-425$.

Stärmülhner (F.). 1976. - Beiträge zur Kenntnis der SüsswasserGastropoden pazifíscher Inseln. Ergebnisse der Österreichischen Indopazifik-Expedition 1971 des 1. Zoologischen Institutes der Universität Wien. Ann. d Naturg. Mus. Wien, 80 : 473-676.

Starmühlner (F.). 1982. -- Occurrence, distribution and geographical range of the freshwater gastropods of the Andaman Islands. Malacologia, $22:$ 455-462.

Statzner (B.) \& Higler (B.). 1985. - Questions and comments on the river continuum concept, Can. J. Fish. Aquatic Sci., $42: 1038-1044$.

Statzner (B.), Gore (J.A.) \& Resh (V.H.). 1988. - Hydraulic stream ecology : observed patterns and potential applications. J. N. Am, Benth. Soc., 7 : 307-360.

Timbol (A.S.) \& Maciolek (J.A.). 1978. - Stream channel modification in Hawaii. Part A. Statewide inventory of streams, habitat factors and associated biota. Fish and Wildife Service, U.S. Dept. of the Interior. FWS/OBS-78/16. 157 p.

Vaillant (F.). 1955. - Recherches sur ta faune madicole (hygropétrique s.1.) de France, de Corse et d'Afrique du Nord. Mém. Mus matn. Hist. nat., Paris, sér. A, $11: 1.258+6 \mathrm{pt}$.

Vannote (R.L.), Minshall (G.W.), Cummins (K.W.), Sedell (J.R.) \& Cushing (C.E.). 1980. - The river continuum concept. Can. J. Fish. Aquatic. Sci., $37: 130-137$.

Wallace (A.R.). 1881, - Island Iife. New-York, Harper and Brothers. $522 \mathrm{p}$.

Williams (H.). 1933. - Geology of Tahiti, Moorea, and Maiao. Bull. Bernice P. Bishop Mus., 105 : 1-89.

Wiliamson (M.). 1981. - Island populations. Oxford. Oxford University Press. 286 p.

Wotton (R.S.). 1979, - The influence of a lake on the distribution of blackfly species (Diptera : Simuliidae) along a river. Oikos, 32 : 368-372. 